\title{
Cloning and functional characterization of a testicular TSH receptor cDNA from the African catfish (Clarias gariepinus)
}

\author{
H F Vischer and J Bogerd \\ Department of Endocrinology, Faculty of Biology, Hugo R Kruyt building, Utrecht University, Padualaan 8, $3584 \mathrm{CH}$ Utrecht, \\ The Netherlands \\ (Requests for offprints should be addressed to J Bogerd; Email: j.bogerd@bio.uu.nl)
}

\begin{abstract}
A cDNA encoding a putative thyroid-stimulating hormone receptor (cfTSH-R) was cloned from the testis of the African catfish (Clarias gariepinus). The cfTSH-R showed the highest amino acid sequence identity with the TSH-Rs of other fish species. In addition, an insertion of approximately 50 amino acids, specific for the TSH-R subfamily, was also present in the carboxy terminus of the amino-terminal extracellular domain of the cfTSH-R. Next to the testis and thyroid follicles, abundant cfTSH-R expression was detected in cerebellum, brain, ovary, seminal vesicles and pituitary, while weaker expression was found in muscle, stomach, intestine, head-kidney, liver, kidney and heart. HEK-T 293 cells, transiently expressing the cfTSH-R, significantly increased intracellular cAMP levels in response to human TSH. Catfish LH, human choriogonadotropin and human FSH were also able to induce this cfTSH-R-mediated response, although with considerably lower efficiency than human TSH. These results indicated that a functional cfTSH-R had been cloned from the testis of African catfish.
\end{abstract}

Journal of Molecular Endocrinology (2003) 30, 227-238

\section{Introduction}

In fish, as in other vertebrates, the pituitary-derived thyroid-stimulating hormone (TSH) and gonadotropins - luteinizing hormone $(\mathrm{LH})$ and folliclestimulating hormone (FSH) - are essential for differentiation, growth and functional regulation of thyroid follicles and gonads respectively. These glycoprotein hormones act on their target tissues via their respective cell membrane receptors. The receptors for TSH, FSH and LH (TSH-R, FSH-R and LH-R respectively) belong to the superfamily of $\mathrm{G}$ protein-coupled receptors, and constitute, together with a restricted number of structurally homologous, invertebrate and vertebrate orphan receptors, the subfamily of leucine-rich repeatcontaining $\mathrm{G}$ protein-coupled receptors (LGR) (Hsu et al. 2000). LGRs are characterized by the presence of multiple leucine-rich repeat (LRR) motifs in their relatively large $\mathrm{N}$-terminal extracellular domains, which have been postulated to adopt a horseshoe-shaped conformation to which their respective (glycoprotein) hormones can bind (Kajava et al. 1995, Bhowmick et al. 1996).

In fish, the biological activity of TSH is primarily directed to thyroid follicles, which are dispersely situated in the basibranchial region within the connective tissue on the surface of the ventral aorta - in contrast to the situation in mammals, where the thyroid follicles are encapsulated into a gland. Moreover, extra-thyroidal TSH-R expression has been reported for several species (e.g. Kumar et al. 2000, Crisanti et al. 2001). In our attempts to clone the testicular cDNA coding for the catfish LH-R (cfLH-R; Vischer \& Bogerd 2003), we unexpectedly isolated a catfish TSH-R (cfTSH-R) cDNA fragment.

Here we report the isolation and functional characterization of the full-length cfTSH-R cDNA and demonstrate its extra-thyroidal expression in numerous tissues of the African catfish. 
Table 1 Primers used in this study

Nucleotide sequence $\left(5^{\prime} \rightarrow 3^{\prime}\right)$

$\begin{aligned} & \text { Primer } \\ & 598^{\mathrm{a}}\end{aligned}$
$599^{\mathrm{a}}$
1041
1042
1043
1044
$1299^{\mathrm{b}}$
1300

GAYGMNTTYAAYCCITGYGARGAYAT

GCRTRIGTHATIGYRTRCCAICKYTC

GTTTCAGCTTCCTCAGGGTGTCTGTTTGGTTTGTCA

CTGACCAGTCATTACAAACTCTCAGTTTCCCGCTTCCTTA

GCGAGGTGACACATAAGGAAGCGGGAAACTGAGAGT

CAAACAGACACCCTGAGGAAGCTGAAACCCATGAT

AAGCCACCATGCGGCTGTTTGCACTTGTGTTAATAACCGTCTTCTCA

AACAGATTTATTGTATCTAACATCTAGTGCTTAACAAA

aPrimers 598 and 599 are degenerate primers, in which $\mathrm{N}=$ any nucleotide, $\mathrm{Y}=\mathrm{T}$ or $\mathrm{C}, \mathrm{R}=\mathrm{G}$ or $\mathrm{A}, \mathrm{M}=\mathrm{A}$ or $\mathrm{C}, \mathrm{K}=\mathrm{G}$ or $\mathrm{T}, \mathrm{H}=\mathrm{A}$ or $\mathrm{T}$ or $\mathrm{C}, \mathrm{D}=\mathrm{G}$ or $\mathrm{A}$ or $\mathrm{T}$, and $\mathrm{I}=$ deoxyinosine.

${ }^{b}$ Primer 1299 contains a consensus translation initiation sequence (Kozak 1984), which is underlined.

\section{Materials and methods}

\section{Animals}

African catfish used in the cloning and tissue distribution experiments were bred and raised in the laboratory as previously described (De Leeuw et al. 1985), except that catfish pituitary extract instead of human chorionic gonadotropin (hCG) was used to induce ovulation. All tissue and sperm samples used in the present study for RNA and genomic DNA isolation were collected from (10- to 12-month-old) sexually mature catfish as regards spermatogenesis (i.e. spermatozoa present in many tubuli). Fish raised in captivity do not differ in testis size or histology from wild fish collected from spawning grounds (Van Oordt et al. 1987, Schulz et al. 1994). However, the captive fish are in a pre-spawning condition; in natural habitats, the full spawning condition is triggered by environmental stimuli (i.e. rainy season, resulting in flooded meadows used as spawning grounds). Ovaries were collected from preovulatory, postvitellogenic adult females. Animal culture and handling was consistent with the Dutch national regulations; the Life Science Faculties Committee for Animal Care and Use approved the experimental protocols.

\section{Glycoprotein hormones}

Catfish LH (cfLH) was isolated from pituitaries of mature catfish as described earlier (Schulz et al. 2001). Human recombinant FSH (hFSH) and hCG were kindly provided by Dr W G E J Schoonen (Organon, Oss, The Netherlands). Human TSH
(hTSH) was purchased from Sigma (St Louis, MO, USA).

\section{Total RNA, poly(A)+ RNA and genomic DNA isolation}

Total RNA was isolated from various tissues (for each tissue, $n=3$ animals) of mature African catfish using the guandinium isothiocyanate method (Chirgwin et al. 1979). Poly(A) ${ }^{+}$RNA was isolated using Dynabeads-oligo dT 25 (Dynal AS, Oslo, Norway), according to the manufacturer's instructions. Genomic DNA was isolated from African catfish sperm according to Strauss et al. (1998).

\section{Primers and PCR}

One microgram testicular RNA was reverse transcribed using oligo-dT $\mathrm{T}_{12-18}$ and the Superscript II preamplification system (Invitrogen, Breda, The Netherlands), according to the manufacturer's instructions. Catfish genomic DNA and testicular cDNA were used as templates in two independent PCR amplifications with degenerate primers 598 and 599 (Table 1) corresponding to highly conserved segments unique for the mammalian glycoprotein hormone receptor family. PCRs were carried out in $50 \mu \mathrm{l}$ volumes containing $50 \mathrm{mM}$ $\mathrm{KCl}, 10 \mathrm{mM}$ Tris- $\mathrm{HCl}$ (pH 8.3), $1.5 \mathrm{mM} \mathrm{MgCl}$, $0.01 \%$ gelatin, $200 \mu \mathrm{M}$ each dNTP, 50 pmol primers and $100 \mathrm{ng}$ DNA template in a PerkinElmer Cetus cycler (Applied Biosystems, Foster City, CA, USA), using $1 \mathrm{U}$ SuperTaq (HT Biotechnologies Ltd, Cambridge, Cambs, UK). PCR was performed under the following cycling 
conditions: denaturation at $94{ }^{\circ} \mathrm{C}$ for $5 \mathrm{~min}$ followed by the addition of Super Taq polymerase at $75^{\circ} \mathrm{C}$, followed by 10 cycles of $94^{\circ} \mathrm{C}$ for $45 \mathrm{~s}$, $37^{\circ} \mathrm{C}$ for $30 \mathrm{~s}$ and $72{ }^{\circ} \mathrm{C}$ for $1 \mathrm{~min}$, and then 25 cycles of $94{ }^{\circ} \mathrm{C}$ for $45 \mathrm{~s}, 55^{\circ} \mathrm{C}$ for $30 \mathrm{~s}$ and $72{ }^{\circ} \mathrm{C}$ for $1 \mathrm{~min}$. DNA fragments of approximately $0.4 \mathrm{~kb}$ were amplified in the two types of PCRs and subcloned into pGEM-T (Promega, Madison, WI, USA) for sequence analysis.

\section{Rapid amplification of cDNA ends}

To isolate the $5^{\prime}$ - and $3^{\prime}$-ends of the presumptive cfTSH-R cDNA, rapid amplification of cDNA ends (RACE) reactions were performed using the SMART RACE cDNA amplification kit (Clontech, Palo Alto, CA, USA). To this end, African catfish testis poly $(\mathrm{A})^{+}$RNA was reversed transcribed to $5^{\prime}$ - and $3^{\prime}$-RACE ready cDNA, according to the manufacturer's instructions. Next, cfTSH-R specific primers (primers 1043 and 1041; Table 1) based on the cloned $0.4 \mathrm{~kb}$ PCR products - were used in combination with a universal primer mix (UPM) for the 5'- and 3'-RACE respectively. The initial $5^{\prime}-$ and $3^{\prime}$-RACE reactions were then followed by nested PCR amplifications using cfTSH-R-specific nested primers (primers 1044 and 1042; Table 1) in combination with the nested universal primer (NUP) respectively. Both the UPM and NUP were supplied with the SMART RACE cDNA amplification kit. All RACE reactions were carried out according to the manufacturer's instructions in a Perkin-Elmer 2400 cycler (Applied Biosystems), using Advantage 2 polymerase (Clontech). RACE products were subcloned into pGEM-T (Promega) and at least two clones derived from at least three independent, nested 5 '- or 3'-RACE reactions were sequenced.

\section{cfTSH-R expression vector construct}

The cfTSH-R open-reading frame was PCR amplified from reverse transcribed testicular mRNA (see above) using the Advantage-HF PCR kit (Clontech) with the primers 1299 and 1300 (Table 1) under the following cycling conditions: $94{ }^{\circ} \mathrm{C}$ for 30 s followed by 10 cycles of $94{ }^{\circ} \mathrm{C}$ for $8 \mathrm{~s}, 53{ }^{\circ} \mathrm{C}$ for $30 \mathrm{~s}$ and $68{ }^{\circ} \mathrm{C}$ for $4 \mathrm{~min}$, and 25 cycles of $94{ }^{\circ} \mathrm{C}$ for $8 \mathrm{~s}, 57^{\circ} \mathrm{C}$ for $30 \mathrm{~s}$ and $68^{\circ} \mathrm{C}$ for $4 \mathrm{~min}$. The resulting PCR product was subcloned into the pcDNA3·1/V5-His-TOPO expression vector (Invitrogen) and sequenced.

\section{DNA sequence analysis and phylogenetic analysis}

DNA sequence analyses were performed on automated ABI PRISM 310 and 377 DNA sequencers, using Dye Terminator cycle sequencing chemistry (all from Applied Biosystems). A homology search was performed using the BLAST 2.0.12 program (Altschul et al. 1990) and alignment of multiple protein sequences using the Megalign program of the Lasergene software package (DNASTAR Inc., Madison, WI, USA) with the Clustal (PAM250) algorithm (Higgins \& Sharp 1990). A phylogenetic tree was constructed from the aligned sequences using the neighbor-joining method (Saitou \& Nei 1987). The putative signal peptide cleavage site was predicted using SignalP V1.1 software (Nielsen et al. 1997), from the CBS prediction server (http://www.cbs.dtu.dk/services).

\section{Transient expression of the putative cfTSH-R in HEK-T 293 cells}

Human embryonic kidney (HEK-T) 293 cells (DuBridge et al. 1987) were maintained under $5 \% \mathrm{CO}_{2}$ in culture medium (Dulbecco's modified Eagle's medium (DMEM) containing $2 \mathrm{mM}$ glutamine, $10 \%$ fetal bovine serum and $1 \times$ antibiotic/antimycotic solution; all from Invitrogen). For colorimetric detection of cfTSH$\mathrm{R}$-mediated ligand-induced cAMP production (see below), transient transfections were performed in a $10 \mathrm{~cm}$ dish, containing approximately $5 \times 10^{6}$ cells, with $1 \mu \mathrm{g}$ cfTSH-R expression vector construct in the presence of $10 \mu \mathrm{g}$ of a pCRE/ $\beta$-gal plasmid, using the modified bovine serum transfection method, according to the instructions of the manufacturer (Stratagene, La Jolla, CA, USA). The pCRE/ $\beta$-gal plasmid consists of a $\beta$-galactosidase gene under the control of a human vasoactive intestinal peptide promotor containing five cAMPresponse elements (Ghen et al. 1995). Five micrograms cfTSH-R expression construct, in the absence of the $\mathrm{pCRE} / \beta$-gal plasmid, was transfected for determining ligand-induced inositol phosphate production (see below). 'Empty' pcDNA3·1/V5-His vector was used for mock transfections. 
Table 2 Primers and TaqMan fluorogenic probes $^{a}$

\begin{tabular}{|c|c|c|c|c|}
\hline & $\begin{array}{l}\text { GenBank } \\
\text { accession } \\
\text { number }\end{array}$ & Primers & Sequence $\left(5^{\prime} \rightarrow 3^{\prime}\right)$ & bp \\
\hline \multicolumn{5}{|l|}{ Target } \\
\hline cfTSH-R & AY129556 & $\begin{array}{l}\text { cfTSH-R-Fw } \\
\text { cfTSH-R-Rv } \\
\text { cfTSH-R-Pr }\end{array}$ & $\begin{array}{l}\text { CCACCATGACTTCCTAAGTAACCTACA } \\
\text { ATGTCCTGGCTGGTGGATACC } \\
\text { CCAAATCCCATATCATGGTAAGAATGCTCATCA }\end{array}$ & 108 \\
\hline cf28S & AF323692 & $\begin{array}{l}\text { cf28S-Fw } \\
\text { cf28S-Rv } \\
\text { cf28S-Pr }\end{array}$ & $\begin{array}{l}\text { TCTCGGAGTCGGGTTGTTTG } \\
\text { CGGTCTCGTGCCGGTATTT } \\
\text { TTTACCACCCGCTTTGGGCTGCA }\end{array}$ & 80 \\
\hline
\end{tabular}

aSequences for the sense (-Fw) and antisense (-Rv) primers and the TaqMan probe (-Pr) as well as the size of the amplicon (base pairs, bp) are shown.

\section{Colorimetric detection of ligand-induced cAMP production}

The $\beta$-galactosidase activity was measured according to Chen et al. (1995) with minor modifications as described previously (Bogerd et al. 2001). Briefly, 16-18 $\mathrm{h}$ after co-transfection of the receptor expression vector construct $(1 \mu \mathrm{g})$ and the pCRE/ $\beta$-gal plasmid $(10 \mu \mathrm{g})$, cells were collected and split into 96-well plates $\left(\sim 2.5 \times 10^{5}\right.$ cells/well $)$. The next day, cells were stimulated for $6 \mathrm{~h}$ with different concentrations of various glycoprotein hormones in $25 \mu \mathrm{l}$ Hepes-modified DMEM containing 0.1\% bovine serum albumin and $0.1 \mathrm{mM} 3$-isobutyl-1methylxanthine (all from Sigma). Ligand-induced changes in absorbance were related to the forskolin-induced changes $(10 \mu \mathrm{M})$ on each 96-well plate. The results are therefore expressed as arbitrary units, related to the forskolin-induced cAMP-mediated reporter gene activation. The agonist concentrations inducing half-maximal stimulation $\left(\mathrm{EC}_{50}\right)$ were calculated using the GraphPad PRISM3 software package (GraphPad Software, Inc., San Diego, CA, USA). All experiments were repeated at least three times using cells from independent transfections, each performed in triplicate.

\section{Detection of ligand-induced inositol phosphate production}

The ligand-induced hydrolysis of $\left[{ }^{3} \mathrm{H}\right]$ phosphatidylinositol was assayed essentially according to Millar et al. (1995). Briefly, $24 \mathrm{~h}$ after transfection with cfTSH-R expression vector construct
$(5 \mu \mathrm{g})$ only, the cells were seeded into 48-well plates $\left(\sim 2.5 \times 10^{5}\right.$ cells/well $)$ in $0.5 \mathrm{ml}$ DMEM supplemented with $10 \%$ dialyzed fetal calf serum containing $1 \mu \mathrm{Ci} / \mathrm{ml}\left[{ }^{3} \mathrm{H}\right]$-inositol (Amersham International plc, Little Chalfont, Bucks, UK). The next day, cells were washed and preincubated for $10 \mathrm{~min}$ with assay medium (Hepes-modified DMEM containing $20 \mathrm{mM} \mathrm{LiCl}$ ). After removing the assay medium, the cells were incubated in $200 \mu \mathrm{l}$ assay medium containing hTSH (1 or $10 \mu \mathrm{g} / \mathrm{ml}$ ) at $37^{\circ} \mathrm{C}$ for $45 \mathrm{~min}$. The assay medium was aspirated and cellular lipids were extracted from the cells by $10 \mathrm{mM}$ formic acid at $4{ }^{\circ} \mathrm{C}$ for $90 \mathrm{~min}$. Total inositol phosphates were separated on Dowex (AG 1X8-200) anion-exchange columns and counted with a scintillation counter. As a positive control for the procedure, HEK-T 293 cells, transiently transfected with a catfish gonadotropin-releasing hormone receptor 1 (cfGnRH-R1; Tensen et al. 1997), were stimulated with $10 \mu \mathrm{M}$ chicken GnRH-II (cGnRH-II).

\section{Analysis of cfTSH-R mRNA tissue distribution by real-time, quantitative PCR}

The relative cfTSH-R mRNA levels in different tissues were determined in a way similar to that described previously (Bogerd et al. 2001). Specific primers and fluorogenic probes for the cfTSH-R mRNA and the endogenous control RNA (i.e. catfish 28S (cf28S) rRNA) are shown in Table 2. Optimization and validation were performed according to the manufacturer's guidelines (Applied Biosystems) and as previously described (Bogerd et al. 2001). 


\section{Statistics}

All results are shown as the mean \pm S.E.M. Statistical analyses to confirm significant hormone-induced over basal signaling were performed using a $t$-test (Statview 4.5; Abacus Concepts, Berkeley, CA, USA). $P$ values $<0.05$ were considered statistically significant.

\section{Results}

\section{Isolation and characterization of the cfTSH-R cDNA}

Degenerate oligonucleotide primers (598 and 599), flanking transmembrane helices 1 and 3 (TM 1 and 3) respectively, and derived from conserved amino acid sequences of vertebrate glycoprotein hormone receptors, were used in two different PCRs with African catfish genomic DNA and testis cDNA respectively as template. Approximately $0.4 \mathrm{~kb}$ PGR products were generated in both types of PCRs, and subsequently subcloned and sequenced. The sequences of these PCR products displayed highest identity to other TSH-Rs. Next, four new cfTSH-R-specific primers were designed based on the sequence of the presumptive cfTSH-R cDNA fragment, and used in RACE reactions in order to isolate the 5'- (primer 1043 and nested primer 1044) and 3 '-ends (primer 1041 and nested primer 1042) of the cfTSH-R cDNA. The combination of $5 '$ - and 3'-RACE reaction products yielded a 2927 bp cDNA sequence (Fig. 1), consisting of an open-reading frame of 2334 nucleotides that was flanked by leader and trailer sequences of 209 and 384 nucleotides respectively. The cfTSH-R openreading frame of $\sim 2.3 \mathrm{~kb}$ was PGR amplified using primers 1299 and 1300 , and subcloned into the pcDNA3-1/V5-His-TOPO expression vector. Sequence analysis of several clones revealed identical sequences to those obtained in the $5^{\prime}$ - and 3'-RACE clones.

A putative translation initiation codon was identified starting at nucleotide position 210 . Conceptual translation of the open-reading frame following this initiation codon predicted a 777 amino acid protein (Fig. 1) of which the first 18 amino acids were predicted to constitute the putative signal peptide (Nielsen et al. 1997). The mature receptor protein displayed typical features of members of the glycoprotein hormone receptor family and consisted of a large extracellular
LRR-containing amino-terminal domain (Ji et al. 1998), followed by a seven TM domain - typical for all members of the rhodopsin-like G proteincoupled family - and an intracellular carboxyterminal domain.

Amino acid sequence alignment of the cfTSH-R with 54 other LRR-containing G protein-coupled receptors was performed using the Clustal method (Higgins \& Sharp 1990). The cfTSH-R protein had the highest amino acid identity to TSH-Rs of other fish species (61-62\%), followed by mammalian TSH-Rs (53-54\%), vertebrate LH-Rs $(40-53 \%)$ and FSH-Rs (40-45\%). The cfTSH-R shared only $14-27 \%$ amino acid identity with vertebrate and invertebrate LGRs. A phylogenetic tree constructed from the aligned amino acid sequences using the neighbor-joining method (Saitou \& Nei 1987) revealed that, next to all LGRs, the glycoprotein hormone receptors were divided into two major groups (Fig. 2). One group consisted of all TSH-Rs, while the other group was further subdivided into two subgroups: all FSH-Rs form one subgroup, whereas the LH-Rs form another subgroup. The cfTSH-R was clearly clustered with all other fish TSH-Rs.

PCR amplification using primers 1041 and 1300 (covering the cDNA region between nucleotides 1444 and 2673; Fig. 1) on genomic DNA of the African catfish yielded an $\sim 1.2 \mathrm{~kb}$ PCR product, indicating that no introns were present in the transmembrane and intracellular carboxy-terminal region of the cfTSH-R gene (data not shown).

\section{Functional characterization of the cfTSH-R}

HEK-T 293 cells, transiently co-transfected with the cfTSH-R expression vector (pcDNA3.1/V5His) construct and the pCRE/ $\beta$-gal reporter plasmid, were challenged with various purified and recombinant glycoprotein hormones, followed by the measurement of intracellular cAMP levels using an indirect colorimetric reporter gene assay (Chen et al. 1995). All tested ligands were able to increase the intracellular cAMP levels significantly in a dose-dependent manner. However, hTSH had by far the highest efficacy $\left(\mathrm{EC}_{50}=25 \pm 3 \cdot 4 \mathrm{ng} / \mathrm{ml}\right)$ in activating the cfTSH-R, whereas at least $1 \mu \mathrm{g} / \mathrm{ml}$ $\mathrm{hFSH}$ and $10 \mu \mathrm{g} / \mathrm{ml} \mathrm{hCG}$ or cfLH were required to enhance significant cfTSH-R-mediated cAMP production (Fig. 3). The glycoprotein hormones tested had no effect on mock-transfected cells (data 
gaaagaactc

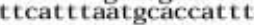
catggttccagctccttgtgtgagctctgatagcgaagaaattcttataggagtctggcaaggatcatacttactgactgtgaaagccaacagactaaa ATG CGG CTG TTT GCA CTT GTG TTA ATA ACC GTC TTC TCA CAT CAA ACC TGC TCT GAG GAT TTT AAT AGC TGC CCT $\begin{array}{llllllllllllllllllllllllllll}M & R & L & F & A & L & V & L & I & T & V & F & S & H & Q & T & C & S & \mathrm{E} & \mathrm{D} & \mathrm{F} & \mathrm{N} & \mathrm{S} & \mathrm{C} & \mathrm{P}\end{array}$ AAA GGA TGT GAA TGC ACA GAA TGG AAG GGG TAT TAT GTT TCG TGT ACA GAT ATT GGT ACC ATG CCT AGG TTT CCT

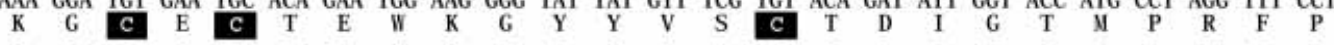

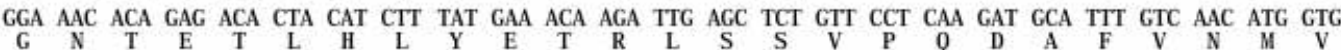
\begin{tabular}{llllllllllllllllllllllllll} 
G & $N$ & T & E & T & L & H & L & Y & E & T & R & L & S & S & V & P & Q & D & A & F & V & N & $M$ & $V$ \\
\hline
\end{tabular}

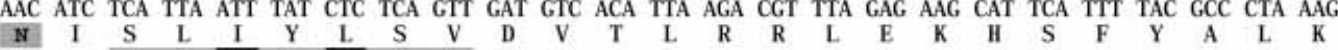

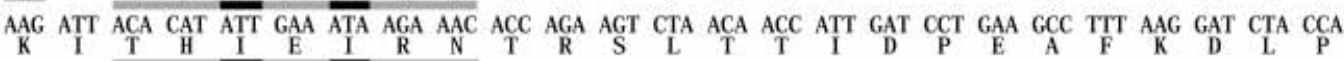
AAG TTA AAA TAC TTA GGT TTG TTC AAT ACA GGT CTC ACC ATT TTT CCT GCA CTG ACA AGG ATC CAC TCT GAG GAG $\begin{array}{lllllllllllllllllllllllll}K & \mathrm{~L} & \mathrm{~K} & \mathrm{Y} & \mathrm{L} & \mathrm{G} & \mathrm{L} & \mathrm{F} & \mathrm{N} & \mathrm{T} & \mathrm{G} & \mathrm{L} & \mathrm{T} & \mathrm{I} & \mathrm{F} & \mathrm{P} & \mathrm{A} & \mathrm{L} & \mathrm{T} & \mathrm{R} & \mathrm{I} & \mathrm{H} & \mathrm{S} & \mathrm{E} & \mathrm{E}\end{array}$

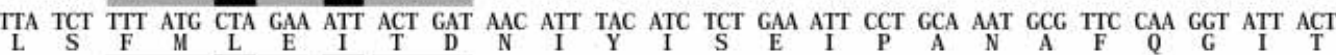
AAA GAT ATG CTA ACA GTA ATG CTA TAC AGT AAT GGC TTT GCT AAA ATC CAA CAC CAC GCC TTC AAT GGG ACA AGC

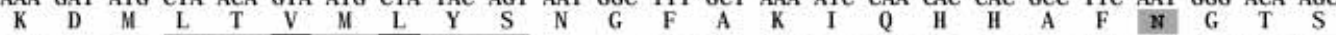

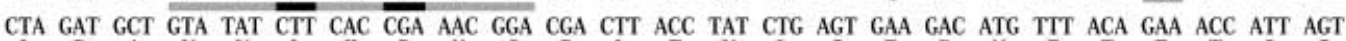

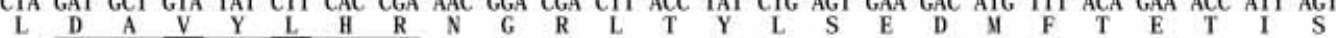
GGT CCT GTG CTG CTT GAT CTT TCA GAC TCC AGA GTT ACA TCG CTT CCA TCG AGG GGA CTG GAG ACA CTC CGG GAA

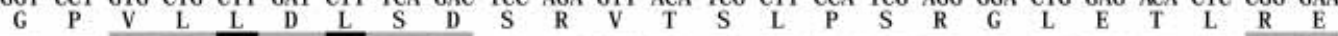
CTC AGT GCT CGA AAT GTT TGG TCT CTT AAA AAG CTC CCA CCA GTT GAA ACT TTC AGA CAT CTG ATT AGT GCT GAT

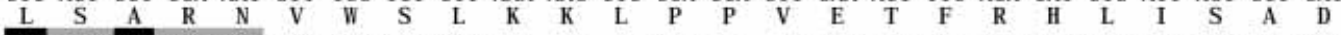
ATG ACT TAT CCT AGT CAC TGC TGT GCC TTC AAG AAC CTT AAG AAA AAG AAA CGG TAC TTG GAT TAC ATA ATT TGT AAC TTG ACT GCG AAG CAT GGC CGA GAC ATT AAA AGA TTA GCC ACT GTT ACA GTT CCA GCT CTC ATG GAT GGA ATA

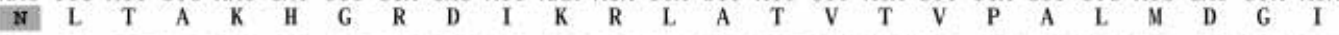
GAC AAA GGC ATT GAC ATG AGT AAC TCC CTA CTG AGA AAA ACC TAT GAC CAC CAT GAC TTC CTA AGT AAC CTA CAT TAT CCT GAC CTT CTT GAT GAG CAT TCT TAC CAT GAT ATG GGA TTT GGG GAC GCA CTA AAG AAT CCT CAG GTA TCC

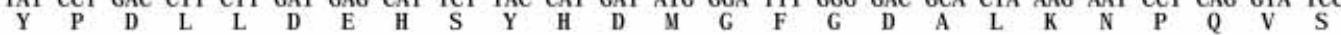
ACC AGC CAG GaC ATT Gat AGC CAT TAT GAT TAT GTT ATA TGT GAG GAT GGa GAA ACC GTG ACA TGC ACC CCA GCT $\begin{array}{lllllllllllllllllllllllllllll}T & S & Q & D & I & D & S & \text { H } & Y & \text { D } & Y & \text { V } & \text { I } & \text { C } & \text { E } & \text { D } & \text { G } & \text { E } & \text { T } & \text { V } & \text { T } & \text { C } & \text { T } & \text { P } & \text { A }\end{array}$ CCT GAT GAC TTC AAC CCT TGC GAG GAC ATC ATG GGT TTC AGC TTC CTC AGG GTG TCT GTT TGG TTT GTC AGT TTG \begin{tabular}{llllllllllllllllllllllllll}
$P$ & $D$ & $D$ & $F$ & $N$ & $P$ & $C$ & $E$ & $D$ & $I$ & $M$ & $G$ & $F$ & $S$ & $F$ & $L$ & $R$ & $V$ & $S$ & $V$ & $W$ & $F$ & $V$ & $S$ & $L$ \\
\hline
\end{tabular} TTG GCT GTA TTT GGA AAT TCA GTG GTA CTC TTT GTG CTG CTG ACC AGT CAT TAC AAA CTC TCA GTT TCC CGC TTC

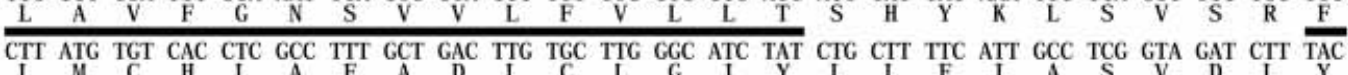

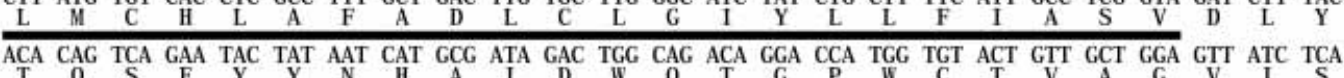
ATC TTT GCA AGT GAG TTG TCA GTT TAC ACT TTG ACC ACT ATC ACT CTG GAG CGC TGG CAT GCC ATC AAT TTT GCA

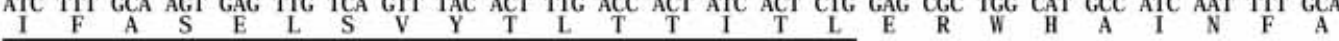
ATG CAA TTA GAT OGT AAG CTG CAT CTG TCC CAT GCA TCT GCT GTC ATG CTA GTG GGT TGG ATC TTA AGC CTC TTG CTT GCC CTT ATG CCT GTG TTG GGG GTG AGC AGT TAC CAA AAG GTC AGC ATA TGT TTG CCCC ATG AGC ACT GAG AAT

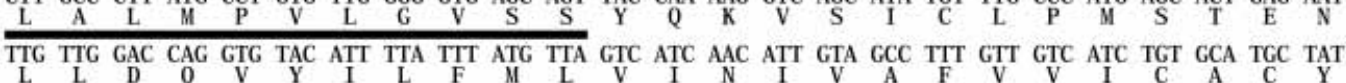

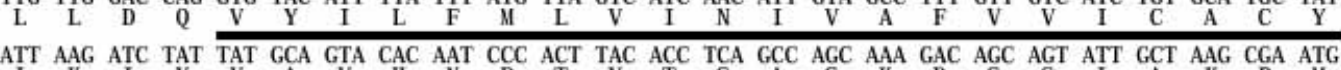

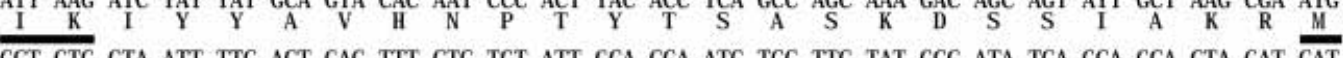

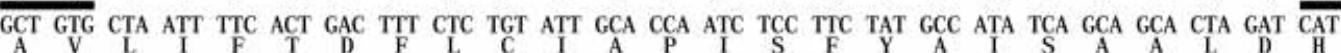
\begin{tabular}{ccccccccccccccccccccccccccc} 
A & V & L & I & F & T & D & F & L & C & I & A & P & I & S & F & Y & A & I & S & A & A & L & D & H \\
\hline CCA & CTC & ATA & TCA & ATT & TCA & AAC & TCC & AAG & ATC & CTG & CTG & GTG & CTC & TTC & TAC & CCT & CTG & AAC & TCA & TGC & GCT AAC & CCT TTT
\end{tabular}

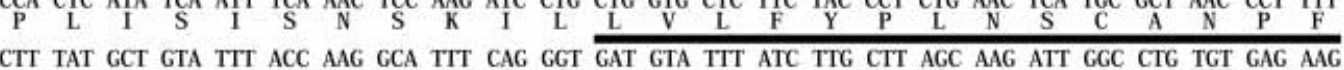

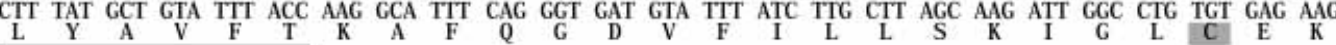

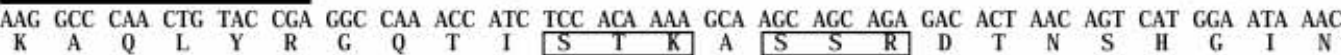
ACA GAA ATC CTA AAA CGA TGG AAT GTT CAG GCC ACT GCT ACC TGT AAC CAA TCC GGT ATC AAA AAA GAC ACT AAC

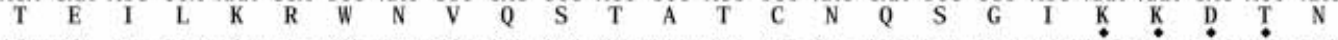
ACA TCA AGA GGC AGG AAA TGT AAA CCT ACT GGC CAT AAA TTC AAG CAA ATC AAA GCG ATG AंC TCंA TGंT GंiT GTA \begin{tabular}{|lllllllllllllllllllllllll}
\hline $\mathrm{T}$ & $\mathrm{S}$ & $\mathrm{R}$ & $\mathrm{G}$ & $\mathrm{R}$ & $\mathrm{K}$ & $\mathrm{C}$ & $\mathrm{K}$ & $\mathrm{P}$ & $\mathrm{T}$ & $\mathrm{G}$ & $\mathrm{H}$ & $\mathrm{K}$ & $\mathrm{F}$ & $\mathrm{K}$ & $\mathrm{Q}$ & $\mathrm{I}$ & $\mathrm{K}$ & $\mathrm{A}$ & $\mathrm{M}$ & $\mathrm{N}$ & $\mathrm{S}$ & $\mathrm{C}$ & $\mathrm{G}$ & $\mathrm{V}$
\end{tabular} TTT TGT TAA gcactagatgttagatacaataaatctgttaaaatgttaaaggtagt ttacaaatgtagtgaaagttgcattagggtgaaaaagttt aacacttcctgtgttcctgtgttgatgaacaggtttccaatttattgccetggtttgttaagctcatgatcccagtcaggcgctggcttgcatt gtt tat gaattatctgattgtatgttgttaat gtctgattgtgtaaactagtctgaatatgtgtaaaactgataat caat caat tcagtt att tatagagcact tt taacaatggtcattgttgcaaagcagct tacagaataaaaagaaataaaaat taaaaaaaaaaaaaaaaaaaaaaaaa 
not shown). Measurement of intracellular inositol phosphate formation in cfTSH-R-expressing HEK-T 293 cells, revealed no significantly increased phospholipase C activity upon stimulation with hTSH (data not shown), whereas HEK-T 293 cells transiently transfected with cfGnRH-R1 showed a clear inositol phosphate response to cGnRH-II, as shown previously (Tensen et al. 1997).

\section{Tissue distribution of the cfTSH-R mRNA}

Tissue-specific expression of the $c f T S H-R$ gene was determined by sensitive real-time, quantitative PCR, and revealed that cfTSH-R mRNA is abundantly present in cerebellum, brain and ovary (Fig. 4). In addition, testis, seminal vesicles, pituitary and conus arteriosus (i.e. the ventral aorta, delivering blood to the gills and surrounded by thyroidal follicles in bony fish) were positive, while weaker expression was detected in all other tissues analyzed (i.e. muscle, stomach, intestine, head-kidney, liver, kidney and heart).

\section{Discussion}

In our attempt to clone cfLH-R DNA fragments (Vischer \& Bogerd 2003) from gonadal tissues and genomic DNA of the African catfish, we unexpectedly PCR amplified a cfTSH-R DNA fragment. The full-length cfTSH-R cDNA was subsequently generated using RACE technology. Analysis of its deduced amino acid sequence revealed that this receptor had the highest identity to other fish TSH-Rs. Interestingly, however, all other fish TSH-Rs had a higher identity to each other $(77-90 \%)$ than each of them to the cfTSH-R $(61-62 \%)$.
In most vertebrate glycoprotein hormone receptor genes, the region for the transmembrane and intracellular carboxy-terminal domains is encoded by a single exon, namely by exon 10 in $F S H-R$ and TSH-R genes and by exon 11 in $L H-R$ genes (Bogerd et al. 2001, Kumar \& Trant 2001). Similar to most other vertebrate glycoprotein hormone receptor genes, the cfTSH-R gene is intronless in this region, which is in contrast to the situation for the salmon glycoprotein hormone receptor (Oba et al. 1999a,b, 2000) and the invertebrate LGR genes (Hauser et al. 1997, Kudo et al. 2000) that all contain introns in this region.

Similar to all other glycoprotein hormone receptors, the cfTSH-R had a relatively large amino-terminal extracellular domain (residues $\mathrm{E}^{19}-\mathrm{R}^{417}$, connected to a rhodopsin-like seven TM domain (residues $\mathrm{V}^{418}-\mathrm{T}^{681}$ ) and followed by an intracellular carboxy-terminal domain (residues $\left.\mathrm{K}^{682}-\mathrm{C}^{777}\right)$. Nine putative LRRs were recognized in the extracellular domain of the cfTSH-R (residues $\mathrm{T}^{53}-\mathrm{H}^{270}$ ), most likely consisting of alternating parallel-arranged $\beta$ strands and $\alpha$ helices (Fig. 1) (Kajava et al. 1995, Bhowmick et al. 1996).

The LRR domain of the cfTSH-R is flanked by $\mathrm{N}$ - and C-terminal cysteine-rich regions (Fig. 1). The cfTSH-R contains four N-terminal cysteines (i.e. residues 24, 28, 30 and 40) that were found to form two disulfide bonds in most glycoprotein hormone receptors, and in such a conformation are important for cell-surface expression (Zhang et al. 1996, Chen et al. 2001). Although the N-terminal cysteine cluster was found not to be involved in TSH binding, it appeared to form an epitope for the binding of thyroid-stimulating autoantibodies (TSAb; the cause of Graves' disease), and was found to be important for TSAb-induced receptor activation (Chen et al. 2001).

Figure 1 Nucleotide sequence and deduced amino acid sequence of the cfTSH-R cDNA. Numbers on the right refer to position of the nucleotides (top) and the amino acid residues (bottom). Amino acid numbering begins with the proposed initial methionine. The predicted signal peptide is indicated in bold italics. Conserved cysteine residues in the $\mathrm{N}$ - and $\mathrm{C}$-terminal cysteine-rich regions of the extracellular domain are indicated by black boxes. The nine identified $\beta$ strand motifs (X-X-L-X-L-X-X) of the leucine-rich repeats, each consisting of a parallel arranged $\beta$ strand and helical segment, are underlined in grey, of which the conserved hydrophobic ' $L$ ' residues within these motifs are underlined in black. Potential N-linked glycosylation sites are indicated by grey boxes. The positions of the seven putative transmembrane $\alpha$ helices of the receptor are underlined in black. A conserved, presumably palmitoylated Cys residue in the intracellular carboxy-terminal domain is indicated by a grey box. Potential sites for cAMP/cGMP-dependent protein kinase and protein kinase $\mathrm{C}$ phosphorylation are indicated by solid diamonds and open boxes respectively. The nucleotide sequence has been submitted to the GenBank and is available under accession number AY129556. 


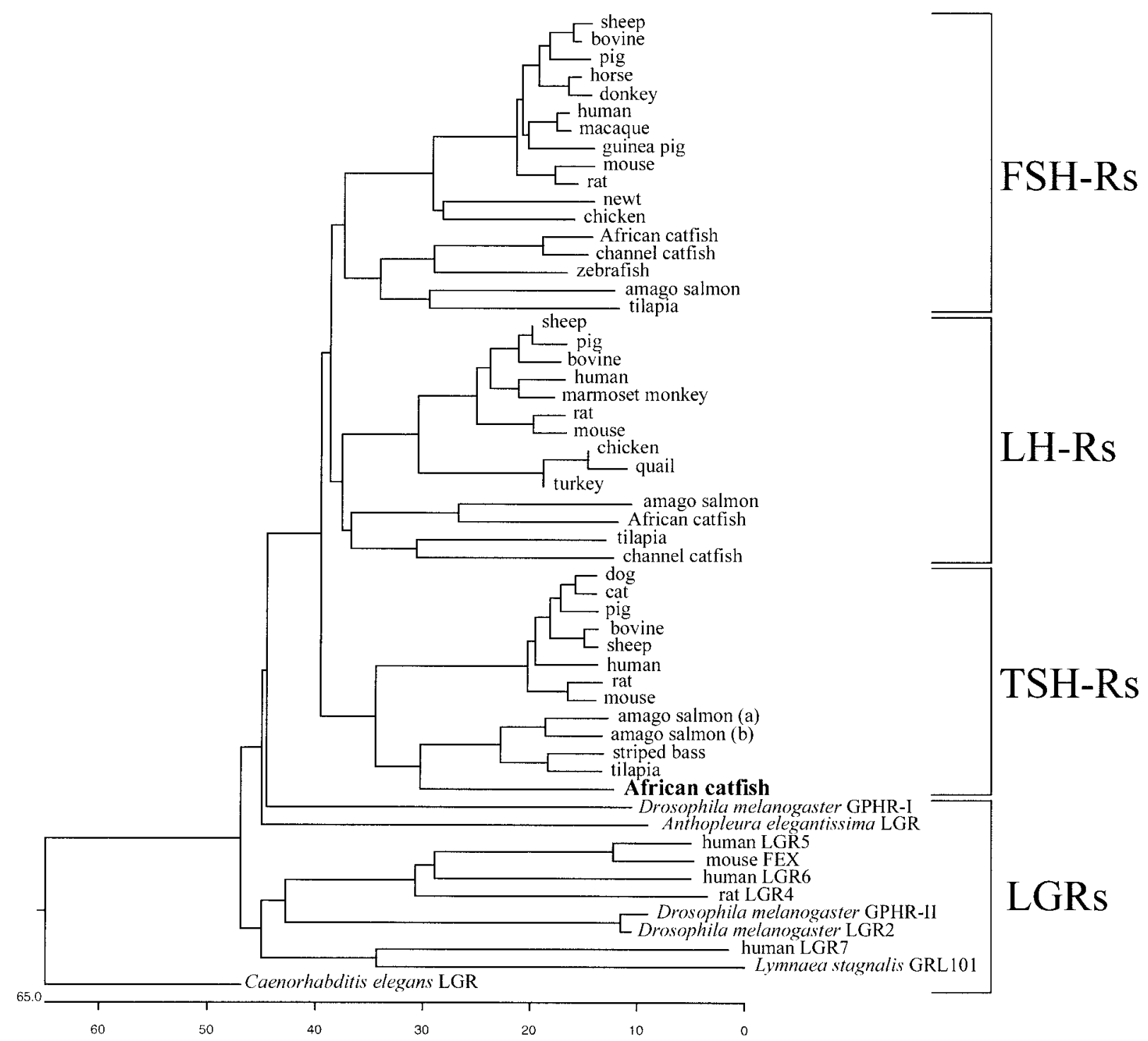

Figure 2 Phylogenetic tree of the leucine-rich repeat-containing, G protein-coupled receptors. The deduced amino acid sequences of 55 LGRs from invertebrate, fish, avian and mammalian species were analyzed using the Clustal method (PAM250) of the Megalign program of the Lasergene software package (DNASTAR). LGRs used: sheep FSH-R (accession number: L07302), bovine FSH-R (L22319), pig FSH-R (AF025377), horse FSH-R (S70150), donkey FSH-R (U73659), human FSH-R (M95489), macaque FSH-R (X74454), guinea pig FSH-R (AY082514), mouse FSH-R (AF095642), rat FSH-R (L02842), newt FSH-R (AB005587), chicken FSH-R (D87871), African catfish FSH-R (AJ012647), channel catfish FSH-R (AF285182), zebrafish FSH-R (AW174149), amago salmon FSH-R (AB030012), tilapia FSH-R (AB041762), sheep LH-R (L36329), pig LH-R (M29525), bovine LH-R (U20504), human LH-R (M63108), marmoset monkey LH-R (U80673), rat LH-R (M26199), mouse LH-R (M81310), chicken LH-R (AB009283), quail LH-R (S75716), turkey LH-R (U92082), amago salmon LH-R (AB030005), African catfish LH-R (AF324540), tilapia LH-R (AB041763), channel catfish LH-R (AF285181), dog TSH-R (P14763), cat TSH-R (AF218264), pig TSH-R (AF338249), bovine TSH-R (U15570), sheep TSH-R (Y13434), human TSH-R (M32215), rat TSH-R (M34842), mouse TSH-R (U02602), amago salmon TSH-Ra (AB030954), amago salmon TSH-Rb (AB030955), striped bass TSH-R (AF239761), tilapia TSH-R (AB047390), African catfish TSH-R (AY129556), Drosophila melanogaster glycoprotein hormone receptor GPHR-I (U47005), Anthopleura elegantissima LGR (Z28332), human LGR5 (AF061444), mouse FEX (AF110818), human LGR6 (AF190501), rat LGR4 (AF061443), Drosophila melanogaster GPHR-II (AF142343), Drosophila melanogaster LGR2 (AF274591), human LGR7 (AF190500), Lymnaea stagnalis GRL101 (Z23104), and Caenorhabditis elegans LGR (AF224743). The scale beneath the tree measures the distance between the sequences, and units indicate the number of substitution events. 


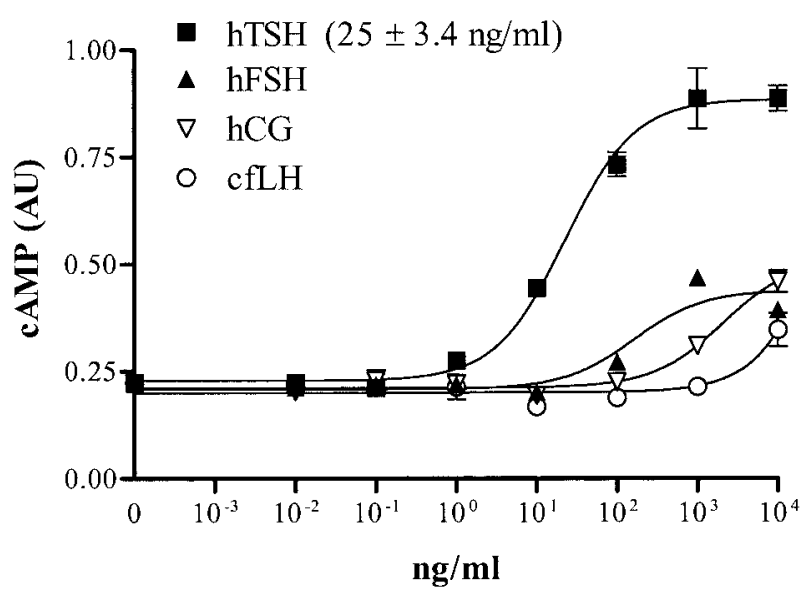

Figure 3 Effects of different glycoprotein hormones on the intracellular cAMP production in HEK-T 293 cells transiently expressing the cfTSH-R. Data are expressed as means \pm S.E.M. of triplicate observations from a single representative experiment in arbitrary units $(A U)$. The value in parentheses represents the $\mathrm{EC}_{50}$ concentration of hTSH and is the average (mean \pm S.E.M.) of four independent assays with triplicate observations each. Due to the low efficiency of hFSH, hCG and cfLH in stimulating the cfTSH-R, it was not possible to calculate the concentrations that induce half-maximum stimulation for these hormones.

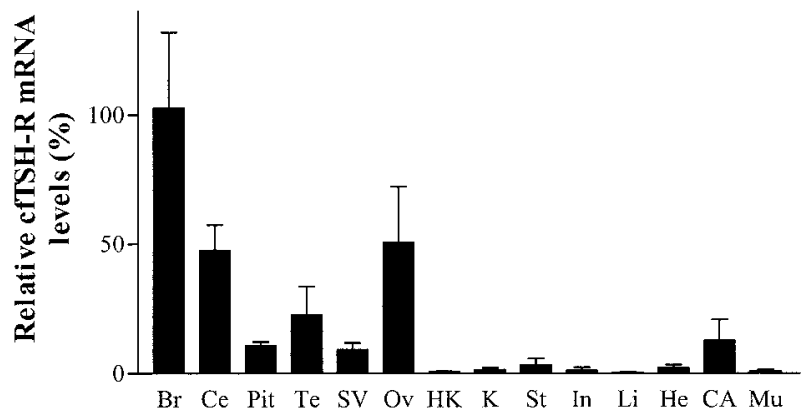

Figure 4 Relative cfTSH-R mRNA levels in different tissues. Data are expressed as percentage of the cfTSH-R mRNA levels (means \pm S.E.M.) in brain, normalized to cf28S rRNA levels, from three individuals that were each analyzed in duplicate. Br, brain without cerebellum; Ce, cerebellum; Pit, pituitary; Te, testis; SV, seminal vesicles (a structure developing from the caudal part of the testis anlage and hence not homologous to mammalian seminal vesicles); Ov, ovary; HK, head-kidney (the adrenal homologue in fish); K, kidney; St, stomach; In, intestine; Li, liver; He, heart; CA, conus arteriosus (i.e. the ventral aorta, delivering blood to the gills and surrounded by thyroidal follicles); Mu, muscle.

The C-terminal cysteine-rich region - also known as the hinge region - of the cfTSH-R contains six cysteine residues (i.e. residues 282, 283,
300, 389, 397 and 407) similar to the situation in all glycoprotein hormone receptors. Despite the presence of two highly conserved amino acid domains (i.e. ${ }^{277}$ TYPSHCCAF $^{285}$ and ${ }^{404} \mathrm{FNP}$ $\mathrm{CEDIMG}^{412}$ ) in the C-terminal cysteine-rich region of the cfTSH-R (see below), the complete $\mathrm{C}$-terminal cysteine-rich region is the least conserved domain between the three glycoprotein hormone receptors (i.e. the LH-R, FSH-R and TSH-R) in both amino acid identity and number. With respect to the latter, the section between the conserved $[\mathrm{T} / \mathrm{S}] \mathrm{YPSHCCAF}$ and FNPCEDIMG regions is the shortest in fish FSH-Rs (44-47 residues), followed by LH-Rs (38-97 residues) and tetrapod FSH-Rs (66-78 residues), whereas this region is the longest in TSH-Rs (117-155 residues; 118 residues in the cfTSH-R). A stretch of approximately 50 amino acids (relative to FSH-Rs and LH-Rs, and corresponding to cfTSH-R segment $\mathrm{V}^{316}-\mathrm{H}^{361}$ ) is often excised from a variable percentage of human TSH-Rs (hTSH-R) that are present on the cell surface as a result of intramolecular cleavage (Chazenbalk et al. 1997). The resulting cleaved N-terminal extracellular domain (the so-called A subunit), however, remained linked to the seven transmembrane domain (the so-called B subunit) due to presumed disulfide bonding between the six C-terminal Cys residues (Tanaka et al. 1999). Hitherto, no functional significance for the TSH-R-specific intramolecular cleavage was identified (Chazenbalk et al. 1999).

The amino acid motif [T/S]YPSHCCAF (corresponding to residues 277-285 in the cfTSH-R) is conserved in all members of the glycoprotein hormone receptor family, and constrains the transmembrane domain of unliganded receptors in the inactive conformation, via an interaction with exoloop 2 of the TM domain (Nishi et al. 2002). In particular, a somatic mutation of SYPSHCCAF to SYPIHCCAF (Ser $\rightarrow$ Ile) in the hTSH-R causes hyperfunctioning thyroid adenomas as a result of a constitutively activated TSH-R (Kopp et al. 1997, Ho et al. 2001).

The conserved FNPGEDIMG (corresponding to residues 404-412 in cfTSH-R), located just upstream of TM 1, was shown to be important for receptor cell-surface expression as well as ligandmediated signaling (Alvarez et al. 1999).

Three potential N-linked glycosylation sites are present in the extracellular domain of the cfTSH-R 
(i.e. ${ }^{76} \mathrm{NIS}^{78},{ }^{197} \mathrm{NGT}^{199}$ and ${ }^{301} \mathrm{NLT}^{303}$ ), whereas four and five of these sites are present in perciform and most mammalian TSH-Rs respectively. The first glycosylation site is unique to TSH-Rs, while the other two sites are also found in other members of the glycoprotein hormone receptor family.

Glycoprotein hormone binding to the N-terminal extracellular domain leads to conformational changes resulting in the activation of the seven TM domain - by means of rotating or tilting helices and the subsequent recruitment of $\mathrm{G}$ proteins that, in their turn, modulate the activity of intracellular effector pathways (Gether 2000, Nishi et al. 2002). Residues important for TM domain functioning as well as its conformation were conserved in the cfTSH-R. Related to its presumed identical function in signaling, the TM domain of the cfTSH-R shares a higher degree of amino acid sequence identity to other TSH-Rs (59-67\%) and both FSH-Rs and LH-Rs (53-60\%), than its hormone specificity conferring N-terminal extracellular domain to other TSH-Rs (47-60\%), FSH-Rs (28-33\%) and LH-Rs (29-41\%).

As in most $G$ protein-coupled receptors, a fourth intracellular loop is introduced into the carboxyterminal domain of the cfTSH-R by presumed palmitoylation of $\mathrm{Cys}^{698}$, which is secured in the cell membrane and has been shown to be important for efficient cell-surface targeting of hTSH-Rs (Tanaka et al. 1998). Four consensus phosphorylation sites were recognized in the carboxy-terminal cytoplasmic tail of the cfTSH-R: ${ }^{711} \mathrm{STK}^{713},{ }^{715} \mathrm{SSR}^{717}$ and ${ }^{751} \mathrm{TSR}^{753}$ are potential protein kinase $\mathrm{G}$ phosphorylation sites, and ${ }^{746} \mathrm{KKDT}^{749}$ is potentially phosphorylated by cAMP- and cGMP-dependent protein kinases. However, although TSH-Rs have been shown to desensitize after TSH binding (Nagayama et al. 1994), probably via receptor phosphorylation, studies using truncated hTSH-Rs revealed that the carboxy-terminal region was not involved in this ligand-dependent desensitization (Haraguchi et al. 1994).

Challenging cfTSH-R-expressing HEK-T 293 cells with a panel of glycoprotein hormones (i.e. cfLH, hFSH, hCG and hTSH) revealed that the cfTSH-R displays a higher ligand selectivity than the other African catfish glycoprotein hormone receptors (cfFSH-R and cfLH-R), as it is only activated by physiological concentrations of hTSH. Promiscuous hormone binding was most obvious in the cfFSH-R (Bogerd et al. 2001), which was equally responsive to cfLH but not to $\mathrm{hCG}$, as the cfLH-R (Vischer \& Bogerd 2003). However, both the $\mathrm{cfFSH}-\mathrm{R}$ and the cfLH-R were responsive to hFSH. Nevertheless, definitive conclusions regarding cfTSH-R ligand selectivity awaits the availability of the endogenous catfish TSH. In contrast to the situation for striped bass (Kumar et al. 2000) and mammalian (Allgeier et al. 1994) TSH-Rs, cfTSH-R signaling is only through the adenylyl cyclase second messenger system. The cfTSH-R does not couple to the inositol phosphate pathway.

Besides the testis, from which the cfTSH-R cDNA was cloned, and the conus arteriosus which is surrounded by thyroid follicles in bony fish and in which tissue one expects its expression, cfTSH-R mRNA expression was detected in all tissues analyzed. Abundant extrathyroidal tissue TSH-R mRNA expression was also observed in the striped bass (Kumar et al. 2000), in which the striped bass TSH-R (stbTSH-R) mRNA was detected in brain, heart, muscle, ovary and testis. In situ hybridizations revealed that the gonadal stbTSH-R mRNA expression was confined to the gametes in both testis and ovary, suggesting a direct role for TSH in gametogenesis, not mediated via surrounding somatic cells. In concert with the above finding, steroid production by African catfish testis tissue fragments was found to be insensitive to TSH stimulation (Bogerd et al. 2001). In contrast to the situation in striped bass and African catfish, salmon TSH-R expression was only observed in the basibranchial region but not in gonads, liver, kidney and brain (Oba et al. 2000). Moreover, extrathyroidal TSH-R expression in mammals has not been reported in the gonads, but was observed in various tissues including fat cells (Endo et al. 1995), lymphocytes (Pekonen \& Weintraub 1978) and brain (Crisanti et al. 2001). However, the physiological relevance of TSH stimulation of the extrathyroidal TSH-R expressing tissues remains to be elucidated.

In conclusion, we have cloned a functional cDNA coding for the cfTSH-R from African catfish testis. Hence, TSH may regulate testis physiology in the African catfish, although TSH did not stimulate steroidogenesis. Future analysis of cfTSH-R spatio-temporal expression may shed light on such a potential physiological role of TSH on the regulation of African catfish testis function. 


\section{References}

Allgeier A, Offermans S, Van Sande J, Spicher K, Schultz G \& Dumant JE 1994 The human thyrotropin receptor activates G-proteins $\mathrm{G}_{\mathrm{s}}$ and $\mathrm{G}_{\mathrm{q} / 11}$. Fournal of Biological Chemistry $\mathbf{2 6 9}$ 13733-13735.

Altschul SF, Gish W, Miller W, Myers EW \& Lipman DJ 1990 Basic local alignment search tool. Fournal of Molecular Biology 251 403-410.

Alvarez CA, Narayan P, Huang J \& Puett D 1999 Characterization of a region of the lutropin receptor extracellular domain near transmembrane helix 1 that is important in ligand-mediated signaling. Endocrinology 140 1775-1782.

Bhowmick N, Huang J, Puett D, Isaacs NW \& Lapthorn AJ 1996 Determination of residues important in hormone binding to the extracellular domain of the luteinizing hormone/chorionic gonadotropin receptor by site-directed mutagenesis and modeling. Molecular Endocrinology 10 1147-1159.

Bogerd J, Blomenröhr M, Andersson E, van der Putten HHAGM, Tensen CP, Vischer HF, Granneman JCM, Janssen-Dommerholt C, Goos HJTh \& Schulz RW 2001 Discrepancy between molecular structure and ligand selectivity of a testicular folliclestimulating hormone receptor of the African catfish (Clarias gariepinus). Biology of Reproduction 64 1633-1643.

Chazenbalk GD, Tanaka K, Nagayama Y, Kakinuma A, Jaume JC, McLachlan SM \& Rapoport B 1997 Evidence that the thyrotropin receptor ectodomain contains not one, but two, cleavage sites. Endocrinology 138 2893-2899.

Chazenbalk GD, Tanaka K, McLachlan SM \& Rapoport B 1999 On the functional importance of thyrotropin receptor intramolecular cleavage. Endocrinology 140 4516-4520.

Chen CR, Tanaka K, Chazenbalk GD, McLachlan SM \& Rapoport BR 2001 A full biological response to autoantibodies in Graves' disease require a disulfide-bonded loop in the thyrotropin receptor $\mathrm{N}$ terminus homologous to a laminin epidermal growth factor-like domain. Fournal of Biological Chemistry 276 14767-14772.

Chen W, Shields TS, Stork PJS \& Cone RD 1995 A colorimetric assay for measuring activation of $\mathrm{G}_{\mathrm{s}}$ - and $\mathrm{G}_{\mathrm{q}}$-coupled signaling pathways. Analytical Biochemistry 226 349-354.

Chirgwin JM, Przybyla AE, MacDonald RJ \& Rutter WJ Isolation of biologically active ribonucleic acid from sources enriched in ribonuclease. Biochemistry 18 5294-5300.

Crisanti P, Omri B, Hughes EJ, Meduri G, Hery C, Clauser E, Jacquemin C \& Saunier B 2001 The expression of thyrotropin receptor in the brain. Endocrinology 142 812-822.

De Leeuw R, Resink JW, Rooyakkers EJM \& Goos HJTh 1985 Pimozide modulates the luteinizing hormone-releasing hormone effect on gonadotropin release in the African catfish, Clarias lazera. General and Comparative Endocrinology 58 120-127.

DuBridge RB, Tang P, Hsia HC, Leong PM, Miller JH \& Calos MP 1987 Analysis of mutation in human cell by using an EpsteinBarr virus shuttle system. Molecular and Cellular Biology 7 379-387.

Endo T, Ohta K, Haraguchi K \& Onaya T 1995 Cloning and functional expression of a thyrotropin receptor $\mathrm{cDNA}$ from rat fat cells. Fournal of Biological Chemistry 270 10833-10837.

Gether U 2000 Uncovering molecular mechanisms involved in activation of G protein-coupled receptors. Endocrine Reviewes $\mathbf{2 1}$ 90-113.

Haraguchi K, Saito T, Kaneshige M, Endo T \& Onaya T 1994 Desensitization and internalization of a thyrotrophin receptor lacking the cytoplasmic carboxy-terminal region. Fournal of Molecular Endocrinology 13 283-288.

Hauser F, Nothacker HP \& Grimmelikhuijzen GJP 1997 Molecular cloning, genomic organization, and developmental regulation of a novel receptor from Drosophila melanogaster structurally related to members of the thyroid-stimulating hormone, follicle-stimulating hormone, luteinizing hormone/choriogonadotropin receptor family from mammals. Fournal of Biological Chemistry $\mathbf{2 7 2}$ $1002-1010$.

Higgins DG \& Sharp PM 1990 Fast and sensitive multiple sequence alignments on a microcomputer. Computer Applications in the Biosciences 5 151-153.

Ho SC, Van Sande J, Lefort A, Vassart G \& Costagliola S 2001 Effects of mutations involving the highly conserved S281HCC motif in the extracellular domain of the thyrotropin (TSH) receptor on TSH binding and constitutive activity. Endocrinology 142 2760-2767.

Hsu SY, Kudo M, Chen T, Nakabayashi K, Bhalla A, van der Spek PJ, van Duin M \& Hsueh AJW 2000 The three subfamilies of leucine-rich repeat-containing $\mathrm{G}$ protein-coupled receptors (LGR): identification of LGR6 and LGR7 and the signaling mechanism for LGR7. Molecular Endocrinology 14 1257-1271.

Ji TH, Grossmann M \& Ji I 1998 G protein-coupled receptors. I. Diversity of receptor-ligand interactions. Fournal of Biological Chemistry 273 17299-17302.

Kajava AV, Vassart G \& Wodak SJ 1995 Modeling of the threedimensional structure of proteins with the typical leucine-rich repeats. Structure 3 867-877.

Kopp P, Muirhead S, Jourdain N, Gu WX, Jameson JL \& Rodd C 1997 Congenital hyperthyroidism caused by a solitary toxic adenoma harboring a novel somatic mutation (serine281 $\rightarrow$ isoleucine) in the extracellular domain of the thyrotropin receptor. Fournal of Clinical Investigation 100 1634-1639.

Kozak M 1984 Compilation and analysis of sequences upstream from the translational start site in eukaryotic mRNAs. Nucleic Acids Research 12 857-872.

Kudo M, Ghen T, Nakabayashi K, Hsu SY \& Hsueh AJW 2000 The nematode leucine-rich repeat-containing, G protein-coupled receptor (LGR) protein homologous to vertebrate gonadotropin and thyrotropin receptors is constitutively activated in mammalian cells. Molecular Endocrinology 14 272-284.

Kumar RS \& Trant JM 2001 Piscine glycoprotein hormone (gonadotropin and thyrotropin) receptors: a review of recent developments. Comparative Biochemistry and Physiology B. Biochemistry and Molecular Biology 129 347-355.

Kumar RS, Ijiri S, Kight K, Swanson P, Dittman A, Alok D, Zohar Y \& Trant JM 2000 Cloning and functional expression of a thyrotropin receptor from the gonads of a vertebrate (bony fish): potential thyroid-independent role for thyrotropin in reproduction. Molecular and Cellular Endocrinology 167 1-9.

Millar RP, Davidson J, Flanagan C \& Wakefield I 1995 Ligand binding and second-messenger assays for cloned $\mathrm{G}_{\mathrm{q}} / \mathrm{G}_{11}$-coupled neuropeptide receptors: the GnRH receptor. In Receptor Molecular Biology, pp 145-162. Ed. SC Sealfon. San Diego: Academic Press.

Nagayama Y, Chazenbalk GD, Takeshita A, Kimura H, Ashizawa K, Yokoyama N, Rapoport B \& Nagataki S 1994 Studies on homologous densensitization of the thyrotropin receptor in 293 human embryonal kidney cells. Endocrinology 135 1060-1065.

Nielsen H, Engelbrecht J, Brunak S \& von Heijne G 1997 Identification of prokaryotic and eukaryotic signal peptides and prediction of their cleavage sites. Protein Engineering 10 1-6.

Nishi S, Nakabayashi K, Kobilka B \& Hsueh AJW 2002 The ectodomain of the luteinizing hormone receptor interacts with exoloop 2 to constrain the transmembrane region: studies using chimeric human and fly receptors. Fournal of Biological Chemistry 277 3958-3964.

Oba Y, Hirai T, Yoshiura Y, Yoshikuni M, Kawauchi H \& Nagahama Y 1999a Cloning, functional characterization, and expression of a gonadotropin receptor cDNA in the ovary and testis of amago salmon (Oncorhynchus rhodurus). Biochemical and Biophysical Research Communications 263 584-590. 
Oba Y, Hirai T, Yoshiura Y, Yoshikuni M, Kawauchi H \& Nagahama Y $1999 b$ The duality of fish gonadotropin receptors: cloning and functional characterization of a second gonadotropin receptor cDNA expressed in the ovary and testis of amago salmon (Oncorhynchus rhodurus). Biochemical and Biophysical Research Communications 265 366-371.

Oba Y, Hirai T, Yoshiura Y, Kobayashi T \& Nagahama Y 2000 Cloning, functional characterization, and expression of thyrotropin receptors in the thyroid of amago salmon (Oncorhynchus rhodurus). Biochemical and Biophysical Research Communications 276 258-263.

Pekonen F \& Weintraub BD 1978 Thyrotropin binding to cultured lymphocytes and thyroid cells. Endocrinology 103 1668-1677.

Saitou N \& Nei M 1987 The neighbor-joining method: a new method for reconstructing phylogenetic trees. Molecular Biology and Evolution 4 406-425.

Schulz RW, van der Corput L, Janssen-Dommerholt J \& Goos HJTh 1994 Sexual steroids during puberty in male African catfish (Clarias gariepinus): serum levels and gonadotropin-stimulated testicular secretion in vitro. Fournal of Comparative Physiology $B$. Biochemical, Systemic, and Environmental Physiology 164 195-205.

Schulz RW, Vischer HF, Cavaco JEB, Santos EM, Tyler CR, Goos HJTh \& Bogerd J 2001 Gonadotropins, their receptors, and the regulation of testicular functions in fish. Comparative Biochemistry and Physiology B. Biochemistry and Molecular Biology 129 407-417.

Strauss WM 1998 Preparation of genomic DNA from mammalian tissue. In Current Protocols in Molecular Biology, pp 2.2.1-2.2.3. Eds
FM Ausubel, R Brent, RE Kingston, DD Moore, JG Seidman, JA Smith \& K Struhl. New York: John Wiley \& Sons, Inc.

Tanaka K, Nagayama Y, Nishihara E, Namba H, Yamashita S \& Niwa M 1998 Palmitoylation of human thyrotropin receptor: slower intracellular trafficking of the palmitoylation-defective mutant. Endocrinology 139 803-806.

Tanaka K, Chazenbalk GD, McLachlan SM \& Rapoport B 1999 Thyrotropin receptor cleavage at site 1 involves two discontinuous segments at each end of the unique 50-amino acid insertion. Journal of Biological Chemistry 274 2093-2096.

Tensen C, Okuzawa K, Blomenröhr M, Rebers F, Leurs R, Bogerd J, Schulz R \& Goos H 1997 Distinct efficacies for two endogenous ligands on a single cognate gonadoliberin receptor. European Fournal of Biochemistry 243 134-140.

Van Oordt PGWJ, Peute J, van den Hurk R \& Viveen WJAR 1987 Annual correlative changes in gonads and pituitary gonadotropes of feral African catfish, Clarias gariepinus. Aquaculture 63 27-41.

Vischer HF \& Bogerd J 2003 Cloning and functional characterization of a gonadal LH receptor cDNA from the African catfish (Clarias gariepinus). Biology of Reproduction 68 262-271.

Zhang R, Buczko E \& Dufau ML 1996 Requirement of cysteine residues in exon $1-6$ of the extracellular domain of the luteinizing hormone receptor for gonadotropin binding. Fournal of Biological Chemistry 271 5755-5760.

Received in final form 8 November 2002 Accepted 24 November 2002 